\title{
Effect of isolates of entomopathogenic fungi in the coconut eye borer
} \author{
Aldomario Santo Negrisoli Junior² (D), João Manoel da Silva'(D) \\ 'Federal University of Alagoas, Rio Largo, Brazil \\ 2Brazilian Agricultural Research Corporation, Maceió, Brazil \\ *Corresponding author, e-mail: hully_monaisy@hotmail.com
}

Hully Monaísy Alencar Lima'*(D), Vanessa de Melo Rodrigues' (D), Anderson Rodrigues Sabino' (D),

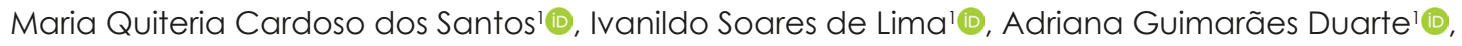

\begin{abstract}
The objective of this study was to evaluate the effect of entomopathogenic fungi on adults of Rhynchophorus palmarum (Coleoptera: Curculionidae). The experimental design was completely randomized in a factorial design (5×3) + control, composed of five treatments (isolated IBCB 66, CPATC 032, CPATC 057 and T9, and the commercial product Boveri $\left.{ }^{\circledR}\right)$ and three concentrations of each fungus $\left(10^{7}, 10^{8}\right.$ and $\left.10^{9} \mathrm{conidia}^{\mathrm{mL}}{ }^{-1}\right)$. The data of confirmed mortality were submitted to analysis of variance (ANOVA) using the Proc ANOVA of SAS, and the means compared by Tukey test at $5 \%$ probability. To determine percentage survival, confirmed mortality data were subjected to Log-Rank test using the Kaplan-Meyer method. Subsequently the values of $\mathrm{LC}_{50}$ and $\mathrm{LT}_{50}$ were estimated submitting mortality confirmed the Probit analysis. For the concentration $10^{8}$ conidia. $\mathrm{mL}^{-1}$, the isolates CPATC 032 and CPATC 057 caused confirmed mortality of 52 and $44 \%$ of the adults of $R$. palmarum, respectively. At the concentration $10^{9}$ conidia. $\mathrm{mL}^{-1}$, the isolates CPATC 032 and CPATC 057 caused mortality of 64 and $52 \%$ of the insects, respectively. For the CPATC 032 isolate, in the three concentrations tested, the insects had an average survival of 11 to 12 days. The $\mathrm{TL}_{50}$ of isolate CPATC 032 at concentrations $10^{8}$ and $10^{9} \mathrm{conidia}^{-\mathrm{mL}^{-1} \text { was }}$ approximately 17 days. All isolates tested and the Boveri ${ }^{\circledR}$ product are pathogenic to R. palmarum.
\end{abstract}

Keywords: Cocos nucifera, Rhynchophorus palmarum, Beauveria bassiana, Trichoderma harzianum

\section{Introduction}

The coconut beetle Rhynchophorus palmarum (Linnaeus, 1758) (Coleoptera: Curculionidae), known in Brazil as coconut eye borer, is a hey-pest of the coconut crop (Cocos nucifera L.) in the Ocidental Indian and in South America (Takada et al., 2014).

The coconut eye borer is responsible to cause direct damage in function of larva feed, and indirect damage, specially by the adult insects, being the principal vectors of the nematode Bursaphelenchus cocophilus (Cobb, 1919) Baujard, 1989 (Nematoda: Aphelenchoididae), which can cause the death of the plant (Cysne et al., 2013).

Knowing that the adult insects of $R$. palmarum are not permanent in the plants, only feed and oviposites inside the coconut stipe, the application of entomopatogenic fungi directly on the insects is non efficient.
Thus, an viable alternative in field is to inocule the fungi in food attractants and make it disponible to the insectos by the pitfalls of autoinoculation, where the insect may come in and out freelly of the putfalls, causing direct mortality inside the pitfalls or spreading the disease in the field.

Considering that there is a great genetic variability in the species of fungi, the selection of isolates is essential in studies of biological control of pests with entomopathogens, in order to establish a natural tool and an ecological and viable alternative to overcome the problems caused by pest insects.

The entomopathogenic fungus Beauveria bassiana (Balsamo) Vuillemin presents a development process in the environment that begins with the adhesion and germination of the conidia to the host integument, in which it involves enzyme production and cell differentiation to ensure colonization and dispersal 
effective (Safavi, 2012; Coutinho-Rodrigues et al., 2016).

The use of fungi of the Trichoderma genre to biological control of pests and diseases is based on the degradation by hydrolytic enzimes. Generally, differents strains of Trichoderma spp. shows differents levels of expression of these enzimes, which leads to differences in the performance where used as agentes of biological control (González et al., 2012).

In acdording to Shakeri \& Foster (2007), chitinase and protease are two of these enzimes responsible to degradation of cellular cell of the phytopathogenic fungi and the cuticle of insects and nematodes, which is composed especially of chitine.

The aim of this study was to evaluate the different concentration of the strains IBC66, CPATC032 and CPATC 057 of B. bassiana, T9 (Trichoderma harzianum) and the commercial strain Boveril ${ }^{\oplus}$ on adults of $R$. palmarum.

\section{Material and Methods}

Place and Instalation

Work was carried out at the Entomology Laboratory of the Brazilian Agricultural Research
Corporation (EMBRAPA) of the Rio Largo Research Execution Unit (REU), located at the Center for Agricultural Sciences (CECA), Federal University of Alagoas (UFAL), Brazil $\left(9^{\circ} 27^{\prime} \mathrm{S}, 35^{\circ} 27^{\prime} \mathrm{W}\right.$ and altitude $\left.127 \mathrm{~m}\right)$, between January and August 2014, the temperature of $26 \pm 1^{\circ} \mathrm{C}$, relative humidity of $60 \pm 10 \%$ and photophase of $12 \mathrm{~h}$.

\section{Adult collect of R. palmarum}

The insects used in the experiment were collected in coconut orchards located in the municipality of Coqueiro Seco, in the Zona da Mata of Alagoas State, Brazil $\left(09^{\circ} 38^{\prime} S\right.$ and $\left.35^{\circ} 48^{\prime} \mathrm{W}\right)$. To capture the adult insects, milkan traps containing sections of sugarcane stalks (Saccharum officinarum L.) (food attractant) plus a commercial pheromone capsule (Rincoforol ${ }^{\circledR}$ ) were used.

\section{Origin of entomopatogenic fungi}

The isolates of $B$. bassiana and T. harzianum used in the study originated from different hosts and locations. The commercial product Boveri ${ }^{\oplus}$, based on the fungus $B$. bassiana, and four fungal isolates were used, three from B. bassiana and one from T. harzianum (Table 1).

Table 1. Origin of the isolates B. bassiana and T. harzianum and the commercial product Boveri ${ }^{\circledR}$ used in the assays with $R$. palmarum.

\begin{tabular}{|c|c|c|c|}
\hline Fungi & Isolate & Host & Location \\
\hline \multirow[t]{4}{*}{ B. bassiana } & $\mathrm{IBCB} 66$ & Hypothenemus hampei(Ferrari, 1867) (Coleoptera: Curculionidae) & São José do Rio Pardo-SP \\
\hline & CPATC 032 & R. palmarum & Aracaju-SE \\
\hline & CPATC 057 & Homalinotus coriaceus (Gyllenhal, 1836) (Coleoptera: Curculionidae) & Aracaju-SE \\
\hline & Boverii ${ }^{\circledR 1}$ & Solenopsis sp. (Westwood, 1840) (Hymenoptera: Formicidae) & Piracicaba-SP \\
\hline T. harzianum & T9 & Solo & Jaguariúna-SP \\
\hline
\end{tabular}

\section{Entomopatogenic fungi viability assay}

The viability of the conidia of all isolates and the commercial product was determined by the germination method, by inoculating $0.1 \mathrm{~mL}$ of suspension of each isolate into two Petri dishes containing agar-agar and spread with the aid of a Drigalsky handle. Then, Petri dishes were incubated in BOD chambers at $25 \pm 1^{\circ} \mathrm{C}$ for $24 \mathrm{~h}$, and light optical microscope readings were performed to find the conidia viability, which was determined by direct counting on the plates. Petri dishes of the germinated and non-germinated conidia (Alves \& Moraes, 1998). For this purpose, the Petri dishes were divided into four quadrants, on which coverslips were placed for reading under a microscope.

Preparation of entomopathogenic fungal suspensions

Sugarcane stalks were plunged into the standard spore suspensions of isolates IBCB 66, CPATC 032, CPATC 057 and $\mathrm{T} 9$, and the Boveril ${ }^{\circledR}$ (commercial product) at concentrations $10^{7}, 10^{8}$ and $10^{9}$ conidia. $\mathrm{mL}^{-1}$ suspension + Will Fix ${ }^{\circledR}$ adhesive spreader $(0.1 \%$ ) for $30 \mathrm{~min}$. In the control treatment, the stems were immersed only in distilled water + Will Fix ${ }^{\circledR}$ adhesive spreader $(0.1 \%)$, during the same period of the other treatments. The adults of $R$. palmarum were separated into a group of 25 insects, transferring them to sealed containers and perforated lids containing the sugarcane stalks previously treated by the fungus, where they remained in contact with the inoculum for $3 \mathrm{~h}$, according to the methodology described by Mendonça (2007).

\section{Fungus inoculation bioassays}

Insects were individualized in plastic containers, and the food (sugarcane stalks), not treated by fungi, replaced every three days. Mortality was evaluated daily for a period of 20 days.

Dead insects were washed with Sodium Hypochlorite (2\%) and subsequently with distilled water to 
clean the surface of the insects and then individualized in plastic containers containing sterile cotton and moistened with sterile distilled water. BOD incubator (temperature $25 \pm 2^{\circ} \mathrm{C}$, relative humidity $70 \pm 10 \%$ and photophase of 12 h), aiming to confirm the mortality through sporulation of the fungi.

\section{Statistical Analysis}

The experimental analysis war completelly randomized in factorial scheme $(5 \times 3)$ and the control treatment, composed by five treatments (strais IBCB 66, CPATC 032, CPATC 057, T9, and the comercia formulation Boveri $\left.{ }^{\circledR}\right)$, and three concentrations to each fungi $\left(10^{7}, 10^{8}\right.$ e $10^{9}$ conidia. $\mathrm{mL}^{-1}$ ). The treatments were constituted of five replications composed by five insects each, totalizing 25 insects/fungi concetration and 25 insects used in control treatment.

Data of confirmed mortality was transformed in arcoseno $\sqrt{(x / 100)}$, and the data from conidia viability of $B$. Bassiana and T. harzianum and the Boveril ${ }^{\circledR}$ were subject to analisys of variance (ANOVA), by the use of Proc ANOVA of SAS 9.0. The means were compared by the Tukey test $(p<0.05)$.

Upon confirmed mortality data of adults from $R$. palmarum, determined the mean live percentage being the data subjected to Log-Rank test by the method of Kaplan-Meyer by pairs of isolates, usein the Proc Lifetest. In determination of the Letal time $\left(\mathrm{LT}_{50}\right)$ the isolates IBCB 66, CPATC 032, CPATC 057 and T9 and Boveril, subjected the confirmed mortality of aduts from $R$. palmarum to Probit analysis. To all analysis were used the software SAS 9.0 (SAS Institute, 2002).

\section{Results and Discussion}

The conidia viability of the isolates IBCB 66, CPATC 032, CPATC 057, and T9, and the commercial product Boveril $^{\circledR}$ showed up suitable, being that the siolates CPATC 057 and IBCB 66 showed, respectivelly, higher and lowerm viability porcentage, do not differing from the other treatments $(F=3.026 ; d f=4 ; P=0.051$ ) (Table 2).

Table 2. Mean $\pm \mathrm{EP}^{\prime}$ of viability (\%) of conidia from Beauveria bassiana and Trichoderma harzianum and the commercial formulation Boveril ${ }^{\circledR}$.

\begin{tabular}{|c|c|}
\hline Treatment & Viability (\%) \\
\hline IBCB 66 & $97.00 \pm 0.82 b$ \\
\hline СРATC 032 & $98.00 \pm 0.82 a b$ \\
\hline CPATC 057 & $99.25 \pm 0.96 a$ \\
\hline Boveril $^{\circledR 2}$ & $98.75 \pm 1.26 \mathrm{ab}$ \\
\hline T9 & $98.25 \pm 0.96 a b$ \\
\hline CV (\%) & 0.99 \\
\hline
\end{tabular}

All the isolates, in three concentrations tested $\left(10^{7}, 10^{8}\right.$, and $10^{9}$ conidia. $\left.\mathrm{mL}^{-1}\right)$, showed pathogenic to adults of $R$. palmarum (Table 3 ). Despite the isolate T9 (T. harzianum) have been pathogenic to adults of $R$. palmarum, penetrating your cuticle, wich is composed principally of chitin (Shakeri \& Foster, 2007), the used concentrations of the fungus do not influence in mortality porcentage.

In concentration $10^{7}$ conidia. $\mathrm{mL}^{-1}$, the mortality porcentage confirmed of Boveri ${ }^{\circledR}$ and the isolates T9, IBCB 66, CPATC 032, and CPATC 057 do not differ each other ( $F=4.16 ; \mathrm{df}=5 ; \mathrm{P}=0.007$ ) (Table 3). Meanwhile Pires et al. (2010) found confirmed mortality of $13 \%$ of caterpillar Tuta absoluta (Meyrick, 1917) (Lepidoptera: Gelechiidae) when feeding them with tomato leaflets sprayed with the suspension of the isolate CPATC 057 in concentration of $10^{7}$ conídia. $\mathrm{mL}^{-1}$.

Rondelli et al. (2012) founf that the commercial formulation Boveril ${ }^{\circledR}$, in concentration of $10^{7}$ conidia. $\mathrm{mL}^{-1}$, was responsible by the confirmed mortality of $86.4 \%$ of caterpillars from traça-das-crucíferas Plutella xylostella (Linnaeus, 1758) (Lepidoptera: Plutellidae), showing higher results in comparation to found in the present study. This high difference in the percentage of mortality probably occurred due to the strong sclerosis of the exoskeleton and the elites of insects belonging to the order Coleoptera (Silva, 2011), making it difficult for the fungus to penetrate, which does not occur in the order Lepidoptera.

For the concentration $10^{8}$ conidia. $\mathrm{mL}^{-1}$, the isolate CPATC 032 caused high mortality, but did not differ significantly from the isolate CPATC 057. The confirmed mortality by Boveri ${ }^{\circledR}$ and the isolates T9 and IBCB 66 also did not differ from each other ( $F=5.02 ; \mathrm{df}=5 ; \mathrm{P}=0.003$ ) (Table 3). In contrast, Giometti et al. (2010) found confirmed mortality of $70 \%$ treating adults of bicudo-do-algodoeiro Anthonomus grandis (Boheman, 1843) (Coleoptera: Curculionidae) with the isolate IBCB 66 in concentration of $10^{8}$ conidia. $\mathrm{mL}^{-1}$. Perhaps, this difference may be associated with the method of application of the fungus directly inside, with a higher mortality rate applicable.

Differences found in confirmed mortality rates may be related to the virulence of the isolates of $B$. bassiana or even by the method of application of the fungus. Lo Verde et al. (2015), treating adults of Rhynchophorus ferrugineus (Olivier, 1790) (Coeloptera: Curculionidae) with isolate $\mathrm{L} 1 \mathrm{of} \mathrm{B}$. bassiana by $30 \mathrm{~s}$ in concentration of $10^{8}$ conidia. $\mathrm{mL}^{-1}$, verify $20 \%$ of confirmed mortality. On the orher hand, Nussenbaum \& Lecuona (2012) verify that $\mathrm{B}$. bassiana $\mathrm{Bb} 23, \mathrm{Bb} 286, \mathrm{Bb} 301$, and 
$\mathrm{Bb} 302$ occasioned mortality of $90-92 \%$ under adults of $\mathrm{A}$. grandis, when treated by 15 seconds with concentration of $5 \times 10^{5}$ conidia. $\mathrm{mL}^{-1}$.

In concentration of $10^{9}$ conidia. $\mathrm{mL}^{-1}$, do not occour significative statistics of Boveril ${ }^{\circledR}$ and the isolates IBCB 66, CPATC 032, and CPATC 057 ( $F=6.83$; $d f=5$; $P=0.004$ ) (Table 3). The isolates T9 from $T$. harzianum occasioned lower mortality in adults of $R$. palmarum.

Table 3. Mean $\pm E^{\prime}$ of confirmed mortality (\%) of adults from Rhynchophorus palmarum fed with sugarcane treated with entomopathogenic fungi in concentration of $10^{7}, 10^{8}$, and $10^{9}$ conidia. $\mathrm{mL}^{-1}$.

\begin{tabular}{|c|c|c|c|c|}
\hline \multirow[b]{2}{*}{ Treatments } & \multicolumn{4}{|c|}{ - } \\
\hline & 0 & $10^{7}$ & $10^{8}$ & $10^{9}$ \\
\hline IBCB 66 & $8.00 \pm 4.29 \mathrm{aB}$ & $4.00 \pm 2.86 \mathrm{aB}$ & $16.00 \pm 5.72 \mathrm{bcAB}$ & $36.00 \pm 6.44 \mathrm{abA}$ \\
\hline СРATC 032 & $8.00 \pm 4.29 \mathrm{aC}$ & $32.00 \pm 5.72 \mathrm{aBC}$ & $52.00 \pm 7.87 \mathrm{aAB}$ & $64.00 \pm 6.44 \mathrm{aA}$ \\
\hline CPATC 057 & $8.00 \pm 4.29 \mathrm{aC}$ & $24.00 \pm 5.72 \mathrm{aBC}$ & $44.00 \pm 9.30 \mathrm{abAB}$ & $52.00 \pm 5.72 \mathrm{aA}$ \\
\hline Boveril ${ }^{\circledR 2}$ & $8.00 \pm 4.29 \mathrm{aB}$ & $8.00 \pm 4.29 \mathrm{aB}$ & $20.00 \pm 3.57 \mathrm{bcAB}$ & $40.00 \pm 7.15 \mathrm{abA}$ \\
\hline T9 & $8.00 \pm 4.29 \mathrm{aA}$ & $4.00 \pm 2.86 \mathrm{aA}$ & $8.00 \pm 4.29 \mathrm{cA}$ & $12.00 \pm 6.44 \mathrm{bA}$ \\
\hline
\end{tabular}

Although the isolate CPATC 032 differed statistically only from the isolate T9, it is likely that the highest mortalityp ercentage of $R$. palmarum caused by this treatment is related to the fact that it is a fungus isolated from the insect under study, providing greater virulence. A similar fact, but with greater efficiency, occurred with Yasin et al. (2019) treating adults of R. Ferrugineus with teh isolate WG 41 of $B$. bassiana from the same specie by 90 seconds in concentrations $10^{7}$ and $10^{8}$ conidia. $\mathrm{mL}^{-1}$, causing mortality of $41.90 \%$ e $75.95 \%$, respectivelly, in adults.

Still in relation to isolate CPATC 032, a close value was found by Mendonça (2007) that, when studying the efficiency of this isolate on adults of $R$. palmarum, fed with sugarcane orevious treated by the fungi in concentration of $10^{9}$ conidia. $\mathrm{mL}^{-1}$ during $3 \mathrm{~h}$, found $61.4 \%$ of insect mortality.

Close result was verified by Nowakonski (2019), who analyzed the pathogenicity of the IBCB 66 isolate from B. bassiana on citrus black fly nymphs Aleurocanthus woglum (Ashby, 1915) (Hemiptera: Aleyrodidae) in the laboratory at concentration $10^{8}$ conidia. $\mathrm{mL}^{-1}$, showing virulent, presenting a mortality of $60.58 \%$ on nymphs on the 4th day of evaluation.

In all treatments, except for the isolated T9, the percentage of mortality observed when the insects were subjected to the concentration $10^{9}$ conidia. $\mathrm{mL}^{-1}$ differed significantly only in relation to the confirmed mortality caused in the control and in the concentration of $10^{7}$ conidia. $\mathrm{mL}^{-1}$ ( $\mathrm{F}=1.68 ; \mathrm{df}=19 ; \mathrm{P}=0.001$ ) (Table 3).

Regarding the average survival, that is, the lifetime of adults from $R$. palmarum after being fed with sugarcane treated with entomopathogenic fungi, in the concentration $10^{7}$ conídios. $\mathrm{mL}^{-1}$ was possible to verify that has significative difference between the isolates CPATC 032, T9, Boveril ${ }^{\circledR}$ and the control $\left(X^{2}=11.50 ; d f=5 ; P=0.042\right)$ (Table 4).

Table 4. Means $\pm \mathrm{EP}^{\prime}$ of survivor (days) in adults of Rhynchophorus palmarum fed sugarcane treated with entomopathogenic fungiin in concentrations of $10^{7}, 10^{8}$, and $10^{9}$ conidia. $\mathrm{mL}^{-1}$.

\begin{tabular}{cccc}
\hline & $10^{7}$ & $10^{8}$ & $10^{9}$ \\
\hline Treatments & - & Concentration (conidia.mL $\mathrm{mL}^{-1}$ ) & - \\
\hline Control & $19.50 \pm 0.50 \mathrm{a}$ & $19.50 \pm 0.50 \mathrm{a}$ & $19.50 \pm 0.50 \mathrm{a}$ \\
IBCB 66 & $13.00 \pm 0.00 \mathrm{abc}$ & $17.75 \pm 0.95 \mathrm{a}$ & $14.78 \pm 1.62 \mathrm{bc}$ \\
CPATC 032 & $12.25 \pm 1.81 \mathrm{c}$ & $11.77 \pm 1.14 \mathrm{c}$ & $12.87 \pm 1.25 \mathrm{~cd}$ \\
CPATC 057 & $13.33 \pm 0.56 \mathrm{abc}$ & $15.91 \pm 1.25 \mathrm{ab}$ & $15.85 \pm 1.18 \mathrm{abc}$ \\
Boveril $^{\oplus 2}$ & $14.50 \pm 0.50 \mathrm{ab}$ & $13.60 \pm 0.51 \mathrm{abc}$ & $12.70 \pm 2.07 \mathrm{~cd}$ \\
T9 & $16.00 \pm 0.00 \mathrm{a}$ & $16.00 \pm 4.00 \mathrm{a}$ & $17.00 \pm 2.52 \mathrm{ab}$ \\
\hline & $X^{2}=11.50^{*}$ & $X^{2}=17.60^{*}$ & $X^{2}=14.83^{*}$ \\
\hline
\end{tabular}

Means followed by the same letter in collums do not differ each other by Log-Rank test by pair of isolates after survivor analysis by method of KaplanMeyer. ${ }^{2}$ Commercial formulation Boveri|ß PM PL63/Koppert Biological Systems, from the fungus Beauveria bassiana. 'Significave to $5 \%$ of probability.

It can be seen that insects fed with sugarcane treated with isolate CPATC 032, in the concentration $10^{8}$ conidia. $\mathrm{mL}^{-1}$ not only differed from the product Boveri ${ }^{\circledR}$ $\left(X^{2}=17.60 ; d f=5 ; P=0.001\right)$ (Table 4). These values differ from the results found by other authors, possibly due to the insects not being in direct contact with the fungal solution. For example, Nussenbaum \& Lecuona (2012) verify that adults of $A$. grandis treated during $15 \mathrm{~s}$ with the isolates of $\mathrm{B}$. bassiana $\mathrm{Bb} 23, \mathrm{Bb} 286, \mathrm{Bb} 301$, and $\mathrm{Bb} 302$, showed middle survivor of 7 to 9 days.

On the other hand, Lo Verde et al. (2015) when treating adults of $R$. ferrugineus with the isolate $L 1$ of $B$. bassiana for $30 \mathrm{~s}$ at the concentration $10^{8}$ conidia. $\mathrm{mL}^{-1}$, found an approximate survival of 23 days. 
The average survival of adults of $R$. palmarum adults exposed to the food treated with the concentration $10^{9}$ conidia. $\mathrm{mL}^{-1}$ of the product Boveril ${ }^{\circledR}$ and of the isolates IBCB 66, CPATC 032 and CPATC 057 did not differ among themselves $\left(X^{2}=14.83 ; d f=5 ; P=0.011\right)$ (Table 4). The results of this study proved to be more efficient than those found by Dembilio et al. (2010), who found that the average survival of adults of $R$. ferrugineus immersed in the fungal suspension of isolate EABb 07/06-Rf from B. bassiana, for 90 s, was 16 days.

By the Probit analysis it was verified that in the concentration $10^{8}$ the isolates CPATC 032 and CPATC 057 showed the best performance during the 20 days of the assay evaluation (17.61 days, 23.11 days, respectivelly) (Table 5).

Table 5. Lethal Time Estimation $\left(\mathrm{LT}_{50}\right)$ for the entomopathogenic fungus in concentration $10^{8} \mathrm{conidia} \cdot \mathrm{mL}^{-1}$ under adults of Rhynchophorus palmarum.

\begin{tabular}{|c|c|c|c|c|}
\hline Isolate & $\mathrm{TL}_{50}$ (days) $(\text { IC 95\%) })^{2}$ & $X^{2(3)}$ & Value $\mathrm{P}^{(4)}$ & $\beta^{(5)}$ \\
\hline IBCB 66 & $24.86(21.66-42.67)$ & 1.53 & 1.00 & 9.61 \\
\hline СРATC 032 & $17.61(15.89-20.31)$ & 4.99 & 0.99 & 3.53 \\
\hline СРATC 057 & $23.11(20.28-29.29)$ & 5.24 & 0.99 & 4.70 \\
\hline Boveril $^{\circledR 1}$ & $25.61(21.84-36.37)$ & 6.96 & 0.99 & 5.11 \\
\hline T9 & $55.79(30.83-13.94)$ & 2.97 & 1.00 & 3.25 \\
\hline
\end{tabular}

$=$ Probability $\left(5 \%\right.$ of significance). ${ }^{5} \beta=$ Slope of the line.

Francardi et al. (2012), when testing the efficiency of $\mathrm{B}$. bassiana $\mathrm{Bba} 01 / \mathrm{TO} 2$ and $\mathrm{Bba} 09 / 101$ isolates in the concentration of $7 \times 10^{6}$ conidia. $\mathrm{mL}^{-1}$ under adults of $R$. ferrugineus, could not determine the $\mathrm{LT}_{50}$. Although the concentration used by the authors is higher than in the present study, the efficiency of the fungal concentrations used in the control of insect pests is related to the variability that exists between the isolates of $B$. bassiana.

In concentration 109, the isolates CPATC 032 e CPATC 057 also presented the best results for the period evaluated (17.25 days, and 21.92 days, respectivelly) (Table 6).

Table 6. Lethal Time Estimation ( $\left.\mathrm{LT}_{50}\right)$ for the entomopathogenic fungus in concentration $10^{9} \mathrm{conídios} . \mathrm{mL}^{-1}$ under adults of Rhynchophorus palmarum.

\begin{tabular}{|c|c|c|c|c|}
\hline Isolate & $\mathrm{LT}_{50}$ (dias) $(\mathrm{Cl} 95 \%)^{2}$ & $x^{2(3)}$ & $P$ value ${ }^{(4)}$ & $\beta^{(5)}$ \\
\hline IBCB 66 & $32.31(24.89-54.15)$ & 9.81 & 0.94 & 2.69 \\
\hline CPATC 032 & $17.25(15.40-20.13)$ & 7.91 & 0.98 & 3.07 \\
\hline СРATC 057 & $21.92(19.44-26.84)$ & 5.81 & 0.99 & 4.49 \\
\hline Boveril ${ }^{\circledR 1}$ & $38.51(26.77-80.16)$ & 4.44 & 0.99 & 1.67 \\
\hline T9 & $42.19(27.67-46.05)$ & 2.93 & 1.00 & 3.98 \\
\hline
\end{tabular}

$=$ Probability $\left(5 \%\right.$ of significance). ${ }^{5} \mathrm{~B}=$ Slope of the line.

Pinto et al. (2012) studying the pathogenicity of isolate IBCB 66, in some application method, in concentration $10^{9}$ conidia. $\mathrm{mL}^{-1}$ under adults of psilídio Diaphorina citri (Kuwayama, 1908) (Psyllidae: Hemiptera), found that the $\mathrm{LT}_{50}$ was 5.7 days. Such results do not corroborate with those found in the present study, possibly because they belong to different insect orders and/or due to the direct contact of these insects with the fungal suspension through spraying.

\section{Conclusions}

The commercial product Boveril ${ }^{\circledR}$ and the isolates IBCB 66, CPATC 032 and CPATC 057 from B. bassiana, and T9 from T. harzianum, are pathogenic to R. palmarum. However, based on the $\mathrm{LT}_{50}$ values, only the use of isolate CPATC 032 is economically viable in the control of $R$. palmarum under laboratory conditions.

\section{Acknowledgment}

To the Coordination for the Improvement of Higher Education Personnel (CAPES), for financial support; and to the company Fitoagro Controle Biológico Ltda; to Embrapa Coastal Tablelands for granting the fungal isolates used in the work; and to Prof ${ }^{a} \mathrm{Dr}^{\mathrm{a}}$ Edna Peixoto Rocha de Amorim for making materials available at the Phytopathology Laboratory of the Universidade Federal de Alagoas.

\section{References}

Alves, S.B., Moraes, S.A. 1998. Quantificação de inóculo de patógenos de insetos. In: Alves, S.B. (ed.). Controle microbiano de insetos. FEALQ, Piracicaba, Brazil. p. 765777.

Coutinho-Rodrigues, C.J.B., Freitas, M.C., Perinotto, W.M.S., Santos, F.S., Fiorotti, J., Quinelato, S., Camargo, M.G., Angelo, I.C., Bittencourt, V.R.E.P. 2016. Estudo morfológico de isolados de Beauveria bassiana antes e após reisolamento em Rhipicephalus microplus. Revista 
Brasileira de Medicina Veterinária 38: 91-97.

Cysne, A.Q., Cruz, B.A., Cunha, R.N.V. Rocha, R.N.C. 2013. Population dynamic Rhynchophorus palmarum (L.) (Coleoptera: Curculionidae) on oil palm trees in the Amazonas State. Acta Amazonica 43: 197-202.

Dembilio, O., Quesada-Moraga, E., Santiago-Álvarez, C., Jacas, J.A. 2010. Potential of an indigenous strain of the entomopathogenic fungus Beauveria bassiana as a biological control agent against the Red Palm Weevil, Rhynchophorus ferrugineus. Journal of Invertebrate Pathology 104: 214-221.

Francardi, V., Benvenuti, C., Roversi, P.F., Rumine, P., Barzanti, G. 2012. Entomopathogenicity of Beauveria bassiana (Bals.) Vuill. and Metarhizium anisopliae (Metsch.) Sorokin isolated from different sources in the control of Rhynchophorus Ferrugineus (Olivier) (Coleoptera Curculionidae). Redia 96: 57-67.

Giometti, F.H.C., Wenzel, I.M.I., Almeida, J.E.M., Leite, L.G., Zappelini, L.O. 2010. Seleção de isolados de Beauveria bassiana para o controle de adultos do bicudo-do-algodoeiro Anthonomus grandis (Coleoptera: Curculionidae). Arquivos do Instituto Biológico 77: 167169.

González, I., Infante, D., Martínez, B., Arias, Y., Gonzáles, N., Miranda, I., Peteira, B. 2012. Induction of chitinases and glucanases in Trichoderma spp. strains intended for biological control. Biotecnología Aplicada 29: 12-16.

Lo Verde, G., Torta, L., Mondello, V., Caldarella, C.G., Burruano, S., Caleca, V. 2015. Pathogenicity bioassays of isolates of Beauveria bassiana on Rhynchophorus ferrugineus. Pest Management Science 71: 323-328.

Mendonça, M.C. 2007. Contribuição ao controle biológico de Rhynchophorus palmarum - atividade de voo, eficiência de autoinoculação e caracterização molecular de isolados de Beauveria bassiana. 97f. (Tese de Doutorado) - Universidade Federal de Alagoas, Maceió, Brazil.

Nowakonski, E.V. 2019. Patogenicidade de fungos entomopatogênicos a mosca-negra-dos-citros, Aleurocanthus woglumi Ashby 1903 (Hemiptera: Aleyrodidae) e Compatibilidade de produtos fitossanitários utilizados na cultura de citros. $59 f$. (Dissertação de Mestrado) - Instituto Biológico, Campinas, Brazil.

Nussenbaum, A.L., Lecuona, R.E. 2012. Selection of Beauveria bassiana sensu lato and Metarhizium anisopliae sensu lato isolates as microbial control agents against the boll weevil (Anthonomus grandis) in Argentina. Journal of Invertebrate Pathology 110: 1-7.

Pinto, A.P.F., Batista Filho, A., Almeida, J.E.M., Wenzel, I.M. 2012. Patogenicidade de Beauveria bassiana ao psilídeo Diaphorina citri e compatibilidade do fungo com produtos fitossanitários. Pesquisa Agropecuária Brasileira 47: 1673-1680.

Pires, L.M., Marques, E.J., Oliveira, J.V., Alves, S.B. 2010. Seleção de isolados de fungos entomopatogênicos para o controle de Tuta absoluta (Meyrick) (Lepidoptera: Gelechiidae) e sua compatibilidade com alguns inseticidas usados na cultura do tomateiro. Neotropical Entomology 39: 977-984.

Rondelli, V.M., Pratisoli, D., Marques, E.J., Santos Junior, H.J.G., Alencar, J.R.C., Sturm, G.M., Paes, J.P.P. 2012. Seleção de isolados de Beauveria bassiana potenciais para o controle da traça-das-crucíferas. Horticultura Brasileira 30: 391-396.

SAS Institute Inc. 2012. Statistical Analysis System user's guide. SAS Institute. Version 9.2, Cary.

Safavi S.A. 2012. Attenuation of the entomopathogenic fungus Beauveria bassiana following serial in vitro transfers. Biologia 67: 1062-1068.

Shakeri, J., Foster, H.A. 2007. Proteolytic activity and antibiotic production by Trichoderma harzianum in relation to pathogenicity to insects. Enzyme and Microbial Technology 40: 961-968.

Silva, S. 2011. Pragas e Doenças de Plantas Forrageiras. Aprenda Fácil, Viçosa, Brazil. 263p.

Takada, H.M., Batista Filho, A., Hojo, H. 2014. Aspectos biológicos de Rhynchophorus palmarum Linnaeus, 1764 (Coleoptera: Curculionidae) em banana-prata (Musa sapientum). Biológico 76: 35-39.

Yasin, M., Wakil, W., Ghazanfar, M.U., Qayyum, M.A., Tahir, M., Bedford, G. 2019. Virulence of entomopathogenic fungi Beauveria bassiana and Metarhizium anisopliae against red palm weevil, Rhynchophorus ferrugineus (Olivier). Entomological Research 49: 3-12.

Conflict of Interest Statement: The authors declare that the research was conducted in the absence of any commercial or financial relationships that could be construed as a potential conflict of interest.

All the contents of this journal, except where otherwise noted, is licensed under a Creative Commons Attribution License attribuition-type BY. 